\title{
Potentials and Challenges of Sustainable Biofuel Development from Biomass Feedstock in Nigeria
}

\author{
Abubakar Sadiq Aliyu ${ }^{1}$, Abdulkarim Ali Deba ${ }^{2}$ \\ ${ }^{1}$ (Department of Mechanical Engineering, College of Engineering \\ Kaduna Polytechnic, Kaduna. Nigeria) \\ ${ }_{2}^{2}$ (Department of Science Education, Faculty of Technology Education Abubakar Tafawa Balewa University \\ Bauchi. Nigeria)
}

\begin{abstract}
Energy is an important factor in all sectors of any national economy. With the rise in oil prices and the adverse effects of global climate change, Nigeria has an unprecedented opportunity of choosing a cleaner development pathway via low-carbon energy alternatives that can reduce the nation's dependence on imported gasoline, reduce environmental pollution while at the same time creating a commercially viable industry that can generate sustainable domestic jobs. The bio-fuel development programme is a unique attempt aim at integrating the agricultural sector of the economy alongside the downstream petroleum sector, while fostering the use of other renewable energy sources. This paper focuses on biofuel development from biomass feedstock with the objective of reviewing the current situation and probable future trends in Nigeria concerning the production of biofuels. A review of these potentials and challenges is presented, which lead to the conclusion that the production and use of biofuels in Nigeria could potentially provide an achievable proposal for economic growth, poverty reduction and environmental sustainability, if the appropriate policies and related institutional and technological innovations are promoted.
\end{abstract}

Keywords: Bio-fuel, Biomass, Environment, Nigeria, Renewable energy.

\section{Introduction}

Nigeria, one of Africa's leading and fastest growing economies, is endowed with sufficient renewable energy resources to meet its present and future development requirements. Nigeria is a major exporter of crude oil globally, with huge revenues accruing from oil sales and exploration licenses and royalties. However, the country faces many challenges including instability in supply and prices of the petroleum products with recurrent acute shortages, land degradation, environmental damage, air pollution and loss of biodiversity resulting from oil exploitation and utilization, serial community conflicts and union disputes, increased poverty and loss of livelihoods in the oil rich Niger Delta, food crises and food insecurity, the lack of basic infrastructure and the collapse of the real sector [1]. Apart from its huge (though declining) petroleum production capacity, Nigeria also has a very high potential for bioenergy production. An initial assessment of the feedstock availability for biofuels production in Nigeria indicates that the country has the potential to be a major biofuelsproducing country [2]. The fact is that its great agricultural potential makes it fit for bio-fuels development. Moreover, while it is understandable that some African countries like Mozambique have embraced bio fuel production from agro biomass as a way of reducing dependence on fuel import, it is logical for Nigeria to appropriate land for bio-fuel production. This therefore led to the assumption that Nigeria's government policy on bio-fuel from agro-biomass amounts to adopting a global trend that can translate to development benefits as a window of economic opportunity for the rural poor [3].

The United Nations Foundation (UNCTAD, 2006), through its Biofuels Initiative launched in June 2005 to promote the sustainable production and use of biofuels in developing countries, states that biofuels have the potential to alleviate poverty, create sustainable rural development opportunities, reduce reliance on imported oil, and increase access to modern energy services [4]. Therefore, bio fuel from biomass has been identified as one of the major drivers of the emergent global land utilization. The conditions for rapid expansion of bio-fuel as alternative energy source seemed to be available in the developed countries. However, suitable bio-fuel crops such as oil palm, cassava, sugarcane, maize, jatropha, etc. are also found in African countries. Similarly, millions of hectares of unused land suitable for Bio-fuels production are believed to be available in many African countries. It is projected that up to one-fifth of the world's agricultural land would be planted in agro-biomass as bio fuel feedstock by 2050 [5]. Presently, only about 14 million hectares of global arable land are devoted to biomass for bio-fuels and it is expected to increase as the project gathers momentum across the globe [6]. Furthermore, developed and emerging nations like Germany, Brazil, Israel, India, China and the United States have acquired large tracts of land and signed investment agreements with some African countries for the purpose of bio-fuels projects. For example, more than 30 companies have been registered in Ethiopia to produce bio-fuels and five have already become operational [7] . Already, Brazil, the leading ethanol bio-fuels 
giant, has planned to establish "Biofuel towns" in Africa in order to spread the bio-fuels revolution in the continent with links to Mozambique, Senegal, Nigeria, Angola, and the African Union for this purpose [7]. At present, Brazil plans to replace 10 per cent of the world's fossil fuels by 2025 with sugar ethanol, Malaysia and Indonesia are expanding oil palm plantations to supply 20 per cent of EU biodiesel needs and India plans to commit $14 \mathrm{~m}$ hectares of land for Jatropha plantations [8-10]. Ironically, Nigeria, a leading fossil fuel producer in Africa, has also targeted 10 per cent use of bio-fuels by 2017 [11]Thus, harnessing this bioenergy potential will provide a premise for solving the various problems related to petroleum fuels highlighted above, while facilitating the development of other real sectors of the economy and enhancing socio-economic development.

\section{Biomass Potential In Nigeria}

Nigeria lies in the western region of Africa and is bordered by the Gulf of Guinea to the south, Niger to the north, Cameroon to the east and Benin Republic to the west. Nigeria's land area is $923,768 \mathrm{~km} 2$. Due to Nigeria's prime location along the equator, the climatic condition throughout the year is generally favorable. Agricultural land constitutes approximately 74,500,000 ha of the total land area of 91,077,000 ha of the country. Approximately $41.2 \%$ of the agricultural land is arable land, $11.3 \%$ forest area and $3.3 \%$ permanently cropped area. Close to $70 \%$ of Nigerian population are involved in agricultural production with more than $70 \%$ of the farming population being smallholder farmers [12]. As represented in Figure 1, the type of biomass resource available in Nigeria varies with climatic region in the country. For example, the rain forest zone will generate the highest quantity of woody biomass while savannah zones will generate more crop residues.

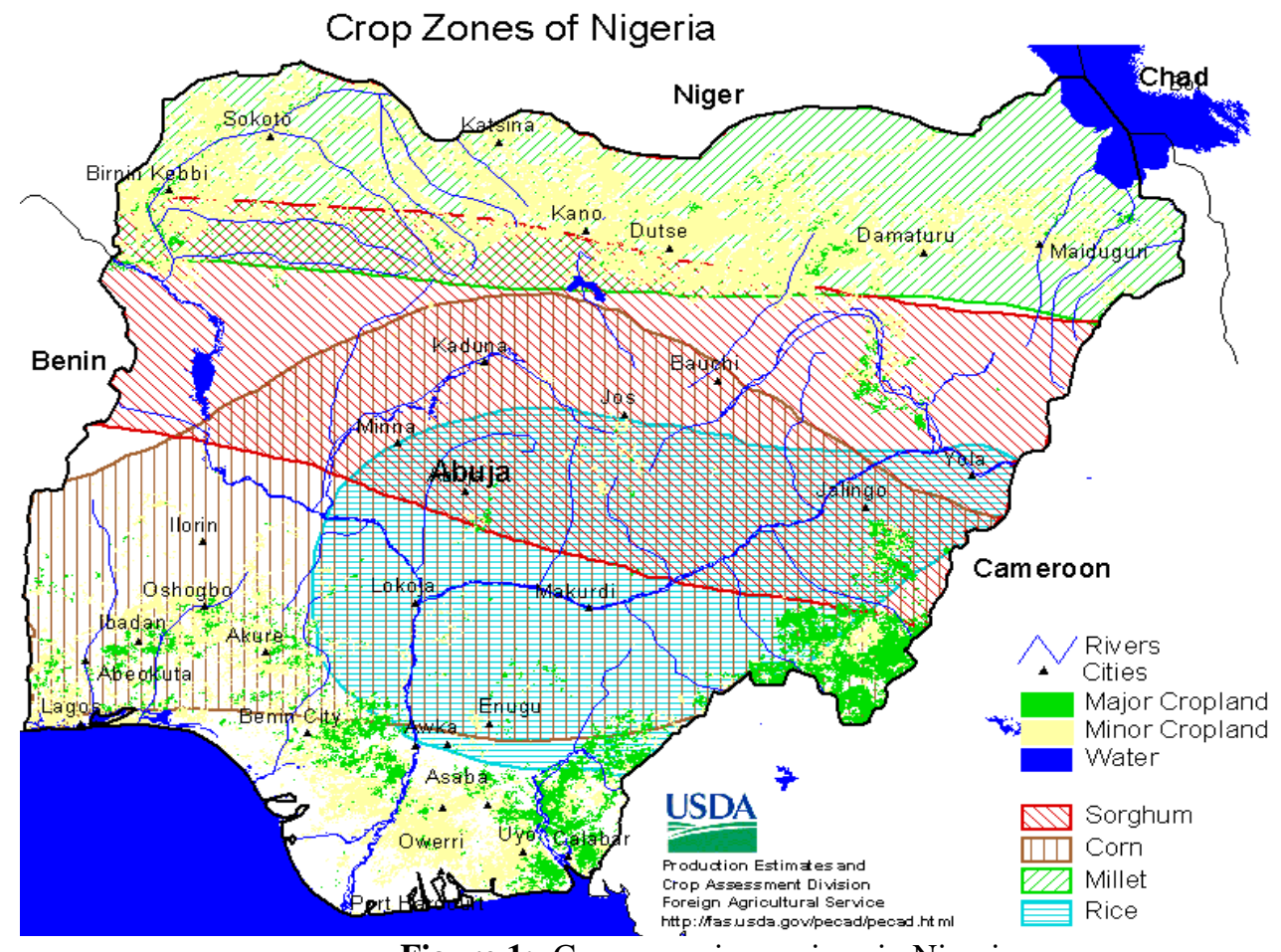

Figure 1: Crops growing regions in Nigeria

The biomass resources of Nigeria are crops, forage grasses and shrubs, animal wastes and waste arising from forestry, agriculture, municipal and industrial activities, as well as aquatic biomass [13] . Therefore, Nigeria has significant potential to produce biofuels and even become an international supplier. Bioenergy feedstock is not only abundant in Nigeria, it is also widely distributed.

\subsection{Bio-fuel Development in Nigeria}

Biofuels are drawing increasing attention worldwide as substitutes for petroleum-derived transportation fuels to help address energy cost, energy security and global warming concerns associated with liquid fossil fuels. The term biofuel is used here to mean any liquid fuel made from plant material. Therefore, bio-fuels are non-petroleum-based liquid fuels, derived largely from plants. Although, biofuels are not expected to totally replace oil-based fuel in the transport system, they are an alternative or a complement to it. Agro-based bio-fuels are divided into three categories, namely first-generation, second-generation and third-generation [14]. Firstgeneration bio-fuels are produced from food crops that include corn, palm oil, soybean, cassava, rapeseed, and sugarcane. In contrast, the sources of second-generation fuels are non-food crops, like switch grass and Jatropha 
curcas, or the residual inedible parts of food crops, such as the husks and stems of corn. Third-generation biofuels are derived from algae. While first-generation agro-fuels are in full-scale production, second and thirdgeneration ones are not yet commercially viable enough to penetrate the global market. Moreover, sources of bio-fuels depends on geographical diversity largely based on existing agricultural production in those regions. Corn-based agro-fuels are dominant in the United States, while sugarcane is used in Brazil, rapeseed in the European Union (EU), and Oil palm is the energy source in Indonesia and Malaysia [15], as indicated in Table 1.

Table 1: Biomass feedstock and Biofuel production in some selected countries.

\begin{tabular}{|c|c|c|}
\hline Country & Feedstock & Biofuel product \\
\hline Brazil & $\begin{array}{c}\text { Sugar cane, Soybean, Palm oil } \\
\text { Castor seed }\end{array}$ & Ethanol, Biodiesel \\
\hline Canada & Corn, Wheat straw, Vegetable oil & Ethanol, Biodiesel \\
\hline China & Corn, Wheat, Cassava & Ethanol, Biodiesel \\
\hline European Union & Wheat, Grains, Sugar beets, Sunflower, Rape seed. & Ethanol, Biodiesel \\
\hline India & Molasses, Sugarcane & Ethanol, Biodiesel \\
\hline Indonesia & Palm oil, Sugar cane, Cassava & Biodiesel \\
\hline Malaysia & Palm oil & Ethanol, Biodiesel \\
\hline Thailand & Molasses, Cassava, Sugar cane, Palm oil & Ethanol, Biodiesel \\
\hline United States & Corn, Soybeans, Oil seed & \\
\hline
\end{tabular}

Source: [16]

In Nigeria, agricultural crops that have potential as biomass feedstock for bio-fuel production include sugar cane, cassava, rice, maize and sorghum for ethanol and oil palm, groundnut, coconut, cotton, soya bean, jatropha and sesame (locally called biniseed) for biodiesel [17] . It is interesting to note that the distribution of plants across different environments is determined by the conditions of weather and soil composition; therefore, biofuel companies will have the opportunity to access feedstocks that thrive during rainfall season from the southern and northern parts of the country [18].Therefore, based on the potential feedstocks available in Nigeria, there is a need for Nigerian government to create a biofuels market in Nigeria and facilitate the development of the necessary infrastructure to support the investment. The underlining objectives here are to promote revenue diversification, create jobs, improve agricultural productivity, and meeting energy needs as well as deriving environmental benefits.

\subsection{Nigerian Bio-fuel Policy}

Government policy has been the fundamental motivator for the revolution in production and expanding market for bio-fuels around the globe. Similarly, government policies have provided financial incentives to the private sector to ensure participation and sustenance of bio-fuels programme. Legislation on bio-fuels is thus becoming very popular and seems to be the standard practice in search of alternative energy source. The bio-fuel regime was meant to gradually reduce the nation's dependence on imported gasoline, reduce environmental pollution and create a commercially viable industry that will guarantee employment. The benefits outlined includes additional tax revenue from the economic activities of the bio-fuel, job creation, development and empowerment of rural communities, improved farming techniques, increased demand for fuel-based crops, reduction in particulate emission and replacement of toxic octane enhancers in gasoline [11] . In promoting biofuels, policy is the main motivating factor for biofuel development. Therefore, both federal and state governments are geared toward promoting biofuels development in Nigeria.

The bio-fuels industry policy program in Nigeria is guided and directed by a three step strategy including planning, building foundation and growth of the industry [19]. The Planning stage involves the development and execution of economic, social, environmental and regulatory assessment within the bio-fuels industry, with promoting financial approach for the purpose of partnership, strategy and partner options. The second phase involves integration of core agricultural production into the bio-fuel programme, which will run concurrently with the seeding programme. This phase is characterized by the establishment of plantations and construction of bio-fuel distilleries and refineries across the country. It is expected to increase to about 2 billion litres by 2020 when market demand for bio-fuel would have risen to about 900 million liters compared to the current market possibility of about $480 \mathrm{~m}$ litres for a $20 \%$ blend for agro-fuel [20] . In accordance with the agrofuel policy, domestic production and consumption of bio-fuel is expected to reach $100 \%$ by 2020 [11]. Presently, efforts are geared towards large scale acquisition of land by NNPC for the production of bio-fuel feedstock such as cassava, maize and sugar cane that are exported for distilling. The policy specifically empowers the Minister of Petroleum Resources under the Petroleum Act to make appropriate regulation that would ensure the availability of bio-fuel for sale and use within Nigeria [11] . However, while Nigeria is vigorously pursuing bio-fuels regime, it does not produce, nor have the technology that use bio-fuels. 


\subsection{Enabling environment}

\section{The Challenges}

Despite the geography and large population that makes Nigeria an ideal renewable energy producers' hub, renewable energy production in Nigeria has its own challenges, hence its penetration has been limited. Moreover, according to [21], poor policy framework was identified as a major challenge confronting commercial-scale production of biofuels in the Nigeria. Therefore, Nigeria's renewable energy resource potential has not been fully exploited, mainly due to the low investment levels as a result of several factors ranging from poor policy implementation by the regulators and more specifically, the absence of an enabling environment. There are also problems around the weak national grid that is unable to wield sufficient energy to the distribution companies. Apart from this, there is the concern that start-up capital costs of renewable power projects in Nigeria are high, relative to other places.

\subsection{Investors}

Nigeria with a history of bio-fuels feedstock mentioned above thus becomes one of the attractive countries for bio-fuels production. Recognizing the high agricultural potential and opportunities for bio-fuels production, the Nigerian state through the NNPC is attracting both foreign and domestic investors into largescale land deals for the production of bio-fuels feedstock in Nigeria as shown in the Table 2 .

Table 2: Land Acquired for bio-fuels feedstock Investments in Nigeria

\begin{tabular}{|c|c|c|c|c|c|c|c|}
\hline Project & Cost & Location & Owners & Feed Stock & $\begin{array}{c}\text { Feed Stock/ } \\
\text { Tonnes }\end{array}$ & $\begin{array}{c}\text { Project } \\
\text { Summary } \\
\text { Production }\end{array}$ & $\begin{array}{c}\text { Land } \\
\text { Hectares }\end{array}$ \\
\hline $\begin{array}{c}\text { Automotive } \\
\text { Biofuel Project }\end{array}$ & $\begin{array}{c}\$ 306 \\
\text { million }\end{array}$ & $\begin{array}{c}\text { Agasha } \\
\text { Guma, } \\
\text { Benue State }\end{array}$ & $\begin{array}{l}\text { NNPC/Private } \\
\text { Sector }\end{array}$ & Sugarcane & 1.8 million & $\begin{array}{c}75 \text { million } \\
\text { L(ethanol), } \\
\text { 116,810 metric } \\
\text { tons (Sugar), } \\
59 \mathrm{MW} \\
\text { (electricity) }\end{array}$ & 20,000 \\
\hline $\begin{array}{c}\text { Automotive } \\
\text { Biofuel Project }\end{array}$ & $\begin{array}{c}\$ 306 \\
\text { million }\end{array}$ & $\begin{array}{c}\text { Bukuru, } \\
\text { Benue State }\end{array}$ & $\begin{array}{c}\text { NNPC/Private } \\
\text { Sector }\end{array}$ & Sugarcane & 1.8 million & $\begin{array}{c}75 \text { million } \\
\text { L(ethanol), } \\
116,810 \text { metric } \\
\text { tons (Sugar), } \\
\text { 59MW } \\
\text { (electricity) }\end{array}$ & 20,000 \\
\hline $\begin{array}{c}\text { Automotive } \\
\text { Biofuel Project }\end{array}$ & $\begin{array}{c}\$ 306 \\
\text { million }\end{array}$ & $\begin{array}{l}\text { Kupto, } \\
\text { Gombe } \\
\text { State }\end{array}$ & $\begin{array}{c}\text { NNPC/Private } \\
\text { Sector }\end{array}$ & Sugarcane & 1.8 million & $\begin{array}{c}75 \text { million } \\
\text { L(ethanol), } \\
116,810 \text { metric } \\
\text { tons (Sugar), } \\
59 \mathrm{MW} \\
\text { (electricity) }\end{array}$ & 20,000 \\
\hline $\begin{array}{c}\text { Automotive } \\
\text { Biofuel Project } \\
\text { (Kwali Sugar } \\
\text { Cane ethanol } \\
\text { Project) }\end{array}$ & $\begin{array}{l}\$ 80-100 \\
\text { million }\end{array}$ & $\begin{array}{c}\text { Kwali } \\
\text { (Federal } \\
\text { Capital } \\
\text { Territory }\end{array}$ & $\begin{array}{c}\text { NNPC/Private } \\
\text { Sector }\end{array}$ & Sugarcane & 1.8 million & $\begin{array}{c}120 \text { million } \\
\text { litres (ethanol), } \\
10-15 \mathrm{MW} \\
\text { (electricity) }\end{array}$ & 26,374 \\
\hline $\begin{array}{c}\text { Automotive } \\
\text { Biofuel Project }\end{array}$ & $\begin{array}{l}\$ 125 \\
\text { million }\end{array}$ & $\begin{array}{c}\text { Ebenebe, } \\
\text { Anambra } \\
\text { State } \\
\end{array}$ & $\begin{array}{c}\text { NNPC/Private } \\
\text { Sector }\end{array}$ & Cassava & 3-4 million & $\begin{array}{c}\text { 40-60 million } \\
\text { L(ethanol) }\end{array}$ & 15,000 \\
\hline $\begin{array}{c}\text { Automotive } \\
\text { Biofuel Project }\end{array}$ & $\begin{array}{l}\$ 125 \\
\text { million }\end{array}$ & $\begin{array}{l}\text { Okeluse, } \\
\text { Ondo State }\end{array}$ & $\begin{array}{l}\text { NNPC/Private } \\
\text { Sector }\end{array}$ & Cassava & 3-4 million & $\begin{array}{l}\text { 40-60 million } \\
\text { L(ethanol) }\end{array}$ & 15,000 \\
\hline Biodiesel 1 & N/A & N/A & $\begin{array}{l}\text { NNPC/Private } \\
\text { Sector }\end{array}$ & Oil Palm & N/A & $\begin{array}{c}40 \text { million } \\
\text { L(biodiesel) }\end{array}$ & 10,000 \\
\hline Biodiesel 2 & N/A & N/A & $\begin{array}{c}\text { NNPC/Private } \\
\text { Sector }\end{array}$ & Oil Palm & N/A & $\begin{array}{c}40 \text { million } \\
\text { L(biodiesel) }\end{array}$ & 10,000 \\
\hline Biodiesel 3 & N/A & N/A & $\begin{array}{c}\text { NNPC/Private } \\
\text { Sector }\end{array}$ & Oil Palm & N/A & $\begin{array}{c}40 \text { million } \\
\mathrm{L}(\text { biodiesel) }\end{array}$ & 10,000 \\
\hline
\end{tabular}

\section{Source: $[22]$}

According to [23], good policies in biofuel development include clear position for small and medium entrepreneurs' benefits that are coherent and can stimulate private and public investment, portray transparent governance and enjoy political will for implementation. Furthermore, a sustainable national policy programme will in addition require that government provides an equitable balance through legislative framework that protects the rights of the small-scale farmers, without becoming over restrictive [24, 25]. In addition, the climatic suitability of the Nigerian environment to the breeding of a wide variety of feedstock makes it sustainable for commercial biofuel production enterprise [25]. Thus, the implementation of the national policy on biofuels and incentives, backed with the required political-will, will attract more investors to Nigeria. 


\section{Conclusion}

The Nigerian climatic condition has immense potential for energy crops cultivation and the production of biofuel. The availability of different types of agricultural crop residues creates enormous potential for biofuel feedstocks. Therefore, with the very high potential for biofuel production, the Government as well as private investors should take steps towards investing in agriculture for the production of energy crops and the establishment of biofuel processing plant. The review critically focuses on biomass resources currently available in Nigeria, and the potential to utilize them for the production of various types of biofuel, which can ease the financial strain related to the heavy burden of fossil fuel subsidy and enhance local livelihood within the production chains. The review shows that a variety of biomass resources exist in the country, and that there is also immense opportunity for their conversion to various types of biofuels using different biomass conversion technologies that are currently available. Thus, with the very high potential for biofuel production, the Government as well as private investors should take steps towards investing in agriculture for the production of energy crops and the establishment of biofuel processing plant in Nigeria. Furthermore, the implementation of the national policy on biofuels will lead to an increased investor's acceptance, hence providing an optimum environment for sustained biofuel production.

\section{References}

[1] N. Abila, " Biofuels adoption in Nigeria: a preliminary review of feedstock and fuel production potentials, Management of Environmental Quality," An International Journal, vol. 21, pp. 785-795, 2010.

[2] N. Abila, "Promting Biofuel Adoption in Nigeria: A Review of Socio-economic Divers and Intensive," presented at the World Renewable Energy Conference, Linkoping Sweeden, 2011.

[3] E. E. Etim, "The Prospect of Biofuels in Complementing the Nigeria's Energy Needs," International Journal of Environmental and Bioenergy, vol. 4, pp. 74-85, 2012.

[4] N. A. Dick, "Analysis of Biofuel Potential in Nigeria," PhD Thesis, School of Agriculture, Food and Rural Development (SAFRD), Newcastle University, Newcasle Upon Tyne, NE1 7RU, United Kingdom, 2014.

[5] T. Wolde-Georgis and M. H. Glantz, "Biofuels in Africa: A Pathway to Development," in International Research Center for Energy and Economic Development Occasional Papers, 2010.

[6] H. Liversage, "Land Access for Rural Development and Poverty Alleviation: An IFAD Perspective " presented at the Presentation at the Global Donor Platform for Rural Developmen Meeting, Rome, 24 January, 2010.

[7] T. Wolde-Georgis and M. H. Glantz, "Biofuels in Africa: A Pathway to Development," 2010.

[8] E. Holt-Gime'nez, "Displaced Peasants, Higher Food Prices, and a Crutch for the Petrol Industry " Global Policy Forum,2010.

[9] J. Vidal. (2007) Climate Change and Shortages of Fuel Signal Global Food Crisis. Guardian Weekly.

[10] M. Altieri, "The Ecological Impacts of Large-Scale Agrofuel Monoculture Production Systems in the Americas," Bulletin of Science, Technology and Society, vol. 29, pp. 236-244, 2009.

[11] NNPC, "Nigerian National Petroleum Corporation (NNPC) (2007), "Nigeriae"s NNPC Launches Four Major Bio-fuel Projects," 2007.

[12] K. J. Simonyan and O. Fasina, "Biomass resources and bioenergy potential in Nigeria (Review)," African Journal of Agricultural Research, vol. 8, pp. 4975-4989, 2013.

[13] C. C. Uzoma, C. E. Nnaji, C. N. Ibeto, C. G. Okpara, O. O. Nwoke, I. O. Obi, et al., "Renewable Energy Penetration in Nigeria: A Study of The South-East Zone," Continental J. Environmental Sciences, vol. 5, pp. 234-239, 2011.

[14] P. Dauvergne and K. J. Neville, "Forests, Food, and Fuel in the Tropics: The Uneven Social and Ecological Consequences of the Emerging Political Economy of Bio-fuels," Journal of Peasant Studies, vol. 37, pp. 631-660, 2010.

[15] J. McCarthy, "Processes of Inclusion and Adverse Incorporation: Oil Palm and Agrarian Change in Sumatra, Indonesia," Journal of Peasant Studies, vol. 37, pp. 821-850, 2010.

[16] F. O. Licht, " Biofuels and the International Development Agenda," World Bioethanol \& Biofuels Reports2005.

[17] A. M. Agba, M. E. Ushie, F. I. Abam, M. S. Agba, and J. Okoro, "Developing the Biofuel Industry for Effective Rural Transformation," European Journal of Scientific Research, vol. 40, pp. 441-449, 2010.

[18] Y. Yahaya, U. A. Birnin-Yauri, B. U. Bagudo, and S. S. Noma, "Effect of seasonal variation on the elemental composition of selected vegetables from fadama areas of Talata Mafara, Zamfara State," Nigeria. American Journal of Environmental Chemistry, vol. 1, pp. 1-11, 2013.

[19] NNPC, "Annual Statistical Bulletin,Corporate Planning and Development Division (CPDD) ", Nigerian National Petroleum Corporation, Abuja Nigeria2008.

[20] O. E. Terungwa, "Bio-fuels, Impact on Food Security: A Case Study of Nigeria"," Master Thesis in the Programme Globalization Environment and Social Change, Stockholm University, Sweden, 2009.

[21] S. C. Izah and E. I. Ohimain, "The challenge of biodiesel production from oil palm feedstock in Nigeria," Greener Journal of Biological Sciences, vol. 3, pp. 1-12, 2013.

[22] E. I. Ohimain, "The Challenge of Liquid Transportation Fuels in Nigeria and the Emergence of the Nigerian Automotive Biofuel Programme," Research Journal of Applied Science Engineering and Technology, vol. 5, pp. 4058-4065, 2013.

[23] O. Chamdimba, "Sustainable development of biofuel in Africa," New Partnership for Africa's Development, Johannesburg, South Africa2009.

[24] P. Simmons, "Overview of smallholder contract farming in developing countries," Food and Agriculture Organization of the United Nations, Rome2002.

[25] B. O. Balogun, "Potential for Sustenable Commercial Biofuels Production in Nigeria," International Journal of Science and Technology (STECH), vol. 4, pp. 25-40, 2015. 